\title{
CORRESPONDENCE
}

\section{Terrorism and Vietnam}

SIR,-Your comments in reply to Lester Goldstein (Nature, 238, 57; 1972) concerning terrorism and Vietnam raise some very important issues. For you a qualitative difference exists between the terrorist act at Tel Aviv airport and what the US government is doing in Vietnam. The former was such that you felt it warranted to raise a hueand-cry about individual acts of terrorism in various parts of the world (Nature, 237, 302; 1972). (In this also you were selective: you mentioned the IRA while omitting the UDA and the British army.) However, you claim that what is happening in Vietnam, be: ing the "consequence of a declared military policy of a government", is not in "Nature's parish".

Why is this so? What is Nature's parish? Would Hitler's gas chambers -a Nazi government policy-and their horrendous use have been outside "Nature's parish"?

Without taking up the question of why the United States government is waging this war (that is, the politics involved), the evidence is overwhelming that what the US is doing is harnessing the most modern concepts in science and technology, on a vast scale, to overcome if not to totally destroy the people and the human environment of a large portion of Indochina. For almost a decade at least, Indochina has been the point of sharpest conflict between advanced technology and the welfare of man and his environment. Never in history has so economically weak and backward a people been subjected to such widespread terror, such destructive energy by so powerful an opponent for so long.

I submit that what the US government is doing in Indochina does fall into "Nature's parish". To hide behind real or imaginary parish boundaries on the issue is no different than to condone the Nazi's genocidal gas chambers. Time is long since past for thinking human beings-including especially scientists and technologists-to view the facts and call for the only possible solution-the immediate and total withdrawal of the US presence from Indochina.

Yours faithfully,

\section{MatTHew HusSey}

Glasgow Dental Hospital and School, 378 Sauchiehall Street,

Glasgow G2 3JZ

\section{Doomwatching}

SIR,--Recent Nature editorials have suggested, in no uncertain terms, that the present spate of warnings about imminent or future "ecocatastrophe" is alarmist and irresponsible. Of course the excesses of the doomwatchers need to be pinpointed, but by the same token of scientific caution it is appropriate to criticize with equal rigour the optimistic view that science can solve everything; and here Nature has been silent.

It should also be remembered that forecasts of disaster, such as the Club of Rome's The Limits of Growth, are not wholly negative: they simply point out what are the probable consequences if certain present trends are continued. I do not accept that it is scientifically reprehensible to do this. Indeed, the environmental lobby surely deserves credit for alerting influential individuals and the general public to the full social and ecological consequences of a purely laissez faire attitude to population, resources, and environment. If, and it is a big "if", concerted steps are now being taken to reduce some of the more dangerous trends, then surely this hopeful development owes something to the efforts of the doomwatchers?

The great human disasters have almost invariably arisen from what has not been predicted, and thus has not been susceptible to corrective control. Science must always tend to be conservative, since facts are retrospective; and so necessarily all our activities will have consequences which we cannot confidently predict. Yet the "civilized" world is constantly engaging in enterprises which must have profound future consequences. Their scale is ever-increasing, so that, once begun, they can slowly and painfully, if at all, be reversed. Typically we have only the most fragmentary firm data from which to predict their socio-ecological effects, so there is usually an uncertain but substantial margin of error. One of the few clear lessons of history is that the increasing scale of our activities and decisions yields a concomitant increase in our mistakes and the magnitude of our disasters. Therefore, if we must err (and that we shall do is a very safe prediction), we should surely err on the side of caution, and be excessively sceptical of optimistic rather than pessimistic assumptions. The effects of taking too much heed of the doomwatchers are unlikely to be as harmful as those of taking too little heed.
Since we are already aware of numerous ecological danger-signals, should not Nature be pressing hard for more and more research on environmental problems, rather than knocking existing "world models" too hard for their imperfections? Science and technology may be able to overcome many of our difficulties (although no doubt many others will require more fundamental political changes), but only if we recognize what the problems are. More and more, especially if we are to be placed in a "public contractor" role, we shall depend on the publicists who can create the political demand for the relevant research funding. Perhaps then, despite their over-zealous excesses, the doomwatchers deserve a little more of Nature's respect.

Yours faithfully,

Department of Psychology,

IAN VINE

8-10 Berkeley Square,

Bristol BS8 $1 \mathrm{HH}$

\section{Abbreviations}

SIR,--In the August issue of the British Journal of Haematology $(23,167 ; 1972)$ is a paper entitled: "Detection of Splenic Anti-Platelet Antibody Synthesis in Idiopathic Autoimmune Thrombocytopenic Purpura (ATP)" by S. Karpatkin, N. Strick and G. W. Siskind. I wish to point out that the abbreviation ATP is already in universal use throughout the biological sciences for adenosine triphosphate. As such the abbreviation is, of course, also used in publications on platelets. The introduction of the same abbreviation for something else, even for a not too common clinical condition, is likely to cause at best irritation and at worst confusion. I should like to urge, therefore, that ATP should not be introduced as an abbreviation for autoimmune thrombocytopenic purpura. (Incidentally the abbreviation ITP, unfortunately already in common use for idiopathic thrombocytopenic purpura, is also the standard abbreviation for inosine triphosphate. There the disease is already established; what one has to do now is to prevent its spread.)

To substantiate the possibility of confusion I should like to tell the following true story. Several years ago, Dr Malcolm Dixon gave a series of lunchtime lectures at University College on ATP and other "high-energy" phosphate compounds. The lectures had a rather popular title which I have now forgotten, 
presumably to attract a wide audience. I do remember, however, that after the first lecture I heard one man say to another behind me: "What an interesting lecturer; but why did he keep referring to Atmospheric Temperature and Pressure?"

$$
\begin{aligned}
& \text { Yours faithfully, } \\
& \text { G. V. R. BoRN }
\end{aligned}
$$

Department of Pharmacology,

Royal College of Surgeons of England, Lincoln's Inn Fields,

London WC2A 3PN

\section{Ethnic Differences}

SIR,-I was pleased to read your unusually well balanced editorial (Nature,
$239,1 ; 1972)$ on the issue of the freedom of research on possible racial differences in intelligence. However, I am afraid that one important point is missing there; that is the question whether intelligence is the only criterion we should be concerned about with respect to the potential ethnic difference in mentality. There are, I think, many other aspects of possible interest and use concerning racial differences in mental activities; aggressiveness may be one, and sense for subtlety may be another. The reason why these are not on the agenda is due to the large framework-of-value system imposed on contemporary society. We have to admit that in all societies research on certain aspects of reality is being unconsciously suppressed. In order to realize this, we have to liberate ourselves from the preoccupation we are all subjected to. What would happen, for example, if it were to be demonstrated that the "quotient of aggressiveness" is significantly higher among one race (say, Caucasians) than others? The stark fact that establishing a scientific measure for aggressiveness has not been explored may simply reflect the inaccessibility to science of those who may be benefited by that type of research.

Yours faithfully, AtUHiro SibatanI 30 Owen Street, Lindfield,

\section{Obituary}

\section{Vsevolod P. Savich}

DR Vsevolod P. SAvich, one of the leading Russian specialists on mosses and lichens, died on May 25, 1972.

Savich was born on February 18, 1885. In 1906, while still a student at the University of St Petersburg, he began working as a laboratory assistant at the Imperial St Petersburg Botanical Gardens (now the "V. L. Komarov" Botanical Institute of the Soviet Academy of Sciences) and soon became interested in the lichens and mosses of the Arctic and sub-Arctic-an interest which, like his association with the Botanical Institute, was to last throughout his life.

Savich's main field of work was the cataloguing and mapping of the mosses and lichens of the Russian Empirelater, of the Soviet Union. He took part in a number of botanical expeditions, of which the most notable were the Kamchatka expedition of 19081910 and the 1930 expedition aboard the icebreaker G. Sedov to Franz Josef Land, Severnaya Zemlya and Vize Island. His collections during the latter expedition extended the known range for Franz Josef Land from forty-three varieties of moss and two hepaticae to eighty-three mosses and seven hepaticae. The data from these expeditions formed the basis of his later taxonomic works.

In 1932, Savich founded the Department of Lower Plants of the Botanical Institute, and became the first head of this department-a post which he was to hold for 30 years. Under his direction, the department soon became the leading body for research into these plants in the whole of the Soviet Union. Under his initiative and general editorship, the Institute published a special series of monographs and other fundamental works devoted to mosses, lichens and fungi. He was also associated with a number of more general journals, including Sovetskaya Botanika, founded in 1933, of which he and V. A. Keller were the first co-editors, and the semi-popular Priroda of which he was editor-in-chief from 1936 to 1951 , a post which he relinquished only when the headquarters of the journal were moved from Leningrad to Moscow.

In addition to his editorial work, $\mathrm{Dr}$
Savich was particularly interested in research into possible medical and other uses of lichens. In particular, he studied the application of lichen resinoids in perfumery and the possibility of obtaining antibiotics and other pharmaceuticals from lichens. The latter line of research led to the discovery of 'Binan' (sodium usninate), which for many years now has been used in surgery and gynaecology in the Soviet Union. With L. V. Lazarov, Savich edited, in 1957, a collection of studies on Binan, to which he, himself, contributed a paper "Lichens, their use in medicine and the obtaining of the new antibiotic Binan".

Dr Savich took an active part in the organization of botanical research throughout the Soviet Union. During the 1930 s he played a leading part in the organization into a single, unified Botanical Institute of the independent Botanical Gardens and Botanical Museum in Leningrad. $\mathrm{He}$ was active as an organizer and editor until his death, working until the end on the current edition of the Novosti sistematiki nizshikh rastenii.

\section{Announcements}

\section{International Meetings}

October 16, Resistance in Arthropods, London (Assistant Secretary, Society of Chemical Industry, 14 Belgrave Square, London SW1X 8PS).

October 19, Non-prescription Antibiotics in Animal Foodstuffs: their Nature and Analysis, London (F. W. Webb, Central Analytical Laboratories (Biological), The Wellcome Foundation Limited, Acacia Hall, Dartford, Kent).
October 20, Training of Food Analysts, Glasgow (Society for Analytical Chemistry, 9-10 Savile Row, London W1X 1AF).

October 25, Physics of Display Devices, London (Meetings Officer, Institute of Physics, 47 Belgrave Square, London SW1X 8QX).

October 27, Geophysical-Statistical Symposium, London (J. M. Craddock, Meteorological Office, London Road, Bracknell, Berkshire RG12 2SZ).

November 2, E. M. Holmes Anniversary Meeting, London (R. E. Marshall, Department of Pharmaceutical Sciences,
Pharmaceutical Society of Great Britain, 17 Bloomsbury Square, London WC1).

November 2, Polymers as Catalysts (Professor Moore Memorial Lecture), Bradford (The Registrar, University of Bradford, Bradford, Yorkshire BD7 1DP).

November 2-4, Neoplasia of Head and Neck, Houston (Mrs Jane Brandenberger, Information Coordinator, University of Texas, M.D. Anderson Hospital and Tumor Institute, Texas Medical Center, Houston, Texas 77025, USA).

November 5-16, Canine Immunogenetics, 